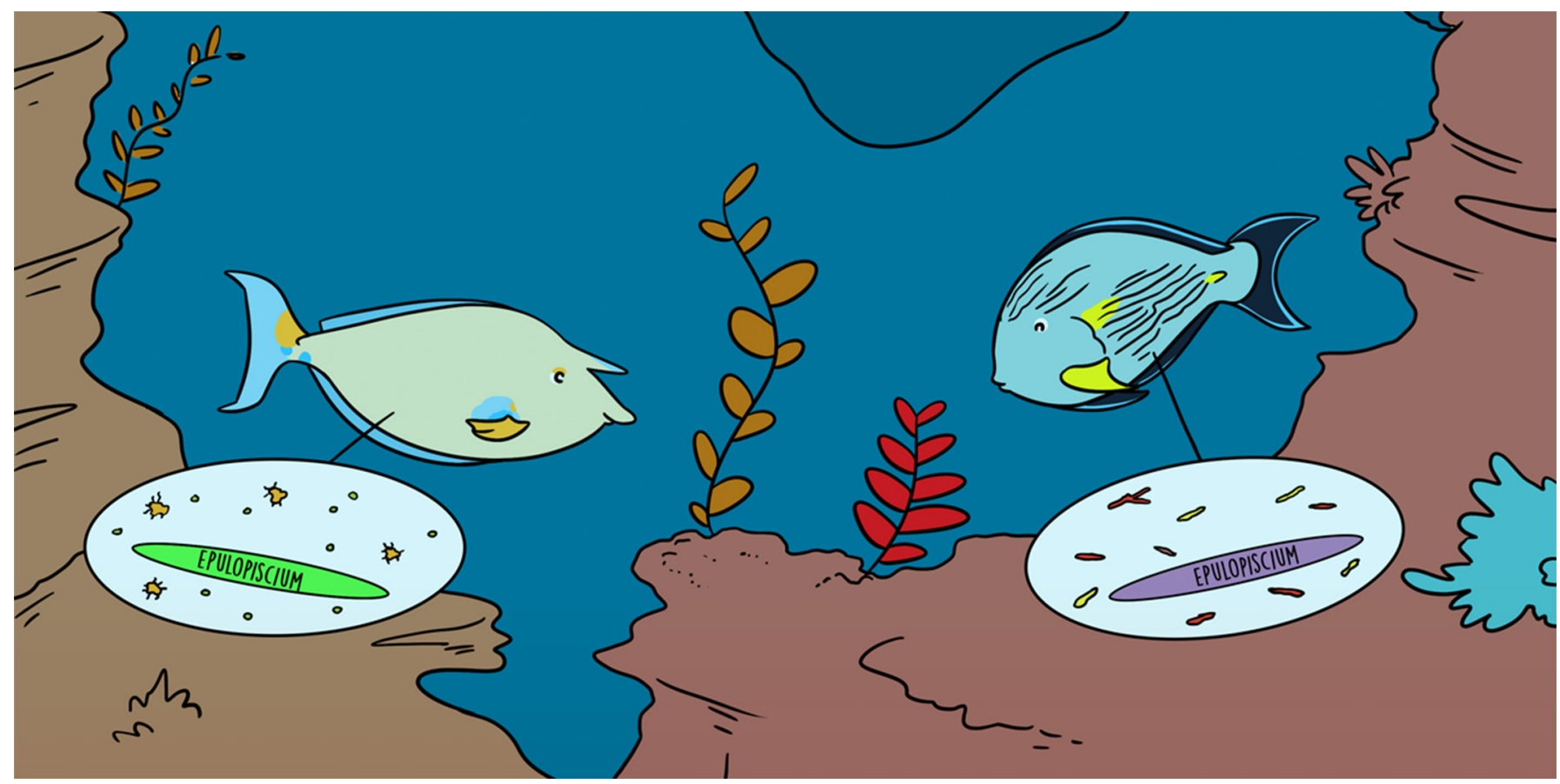

\title{
A UNIQUE BELLYFUL: EXTRAORDINARY GUT MICROBES HELP HERBIVOROUS FISH EAT SEAWEEDS
}

\section{Matthew D. Tietbohl ${ }^{1 *}$, David Kamanda Ngugi ${ }^{2}$ and Michael L. Berumen ${ }^{1}$}

${ }^{1}$ Division of Biological and Environmental Science and Engineering, Red Sea Research Center, King Abdullah University of Science and Technology, Thuwal, Saudi Arabia

${ }^{2}$ Leibniz Institute DSMZ - German Collection of Microorganisms and Cell Cultures GmbH Department of Microorganisms, Braunschweig, Germany

\section{YOUNG REVIEWERS:}

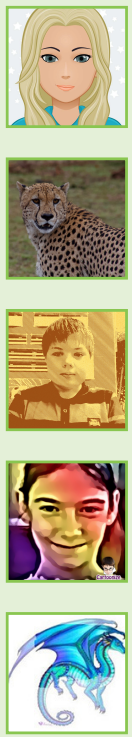

ALANA

AGE: 12

IDHANT

AGE: 12

KONSTANTIN

AGE: 12

LILIAN

AGE: 11

SHIRHAN

AGE: 12
All animals rely on a unique community of microbes to help digest food. This is especially true for plant-eating animals, which need a complex mix of gut bacteria, also known as microbes, to digest the tough plant material they eat. However, when it comes to herbivorous animals in the sea, like some fish, we know much less about the role microbes play in helping to digest food. Marine algae, better known as seaweeds, are unlike land plants in many ways, so herbivorous fish species likely have unique ways of digesting them. Therefore, we investigated the gut microbes in several herbivorous fishes in the Red Sea to see how they help fish digest algae. Surprisingly, we found that even though these fish had unique gut microbe communities, all were made up by varieties of one type of giant bacteria that appears to have evolved to help them digest their favorite algae! 


\section{POLYSACCHARIDE}

An energy source that is made up of sugar molecules linked together in a chain, for example, table sugar. Table sugar is a polysaccharide made up by two single sugar molecules-glucose and fructose-linked together.

\section{ENZYME}

A molecule that helps to speed up chemical reactions. In digestion, enzymes are used to break chemical bonds between molecules to produce smaller, easier-to-digest molecules, a bit like scissors.

\section{MICROBE}

Tiny living things found in the environment all around us and inside us. They include kinds of bacteria, and related germs. They play a key role in helping animals digest their food.

\section{THE IMPORTANCE OF SLIMY SEAWEED}

What do you think about when you hear the word seaweed? Does it sound tasty to you? While many people think of seaweed, known to scientists as marine algae, as a slimy and smelly green mass they get tangled in at the beach or lake, many animals actually think algae is quite delicious! This is especially true of plant eating fishes, also called herbivorous fishes, that are found on coral reefs, which have become specialized in feeding on different types of algae. Algae come in many different shapes and sizes, from algae that form short, grass-like lawns growing on underwater rocks, to large, tough bush-like forms. Algae form important habitats for many animals, but too much algae can kill or overgrow corals. This can lead to coral reefs losing the complex structure that allows them to house thousands of species. Fish that eat algae play an important role, by controlling the amount of algae that grows on coral reefs. When they remove algae, they also create new space where corals or other animals can settle down and grow. By eating algae, they help keep coral reefs healthy and clear of most algae, which allows corals to grow and thrive, creating more habitat for other fish and animals to live!

There is, however, a big problem these herbivorous fishes face when they eat algae. It is not easy to digest! Algae, like all living things, are made up of cells, with each specialized for a certain role. The cells of algae hold complex, large chains of sugars, called polysaccharides (pronounced, "pol-ee-sack-ah-ride"). Different algae have their own, unique composition of these large sugar chains within their cells (Figure 1). To get energy from algae, herbivorous fishes need to break down these large chains. Inside the guts of fish are molecules known as enzymes (think of them as molecular or chemical scissors) that can break these sugar chains into smaller parts fish can absorb into their bodies. There are many different types of these enzymes, functioning like different workers on a construction team. Each enzyme has a specific job in breaking down different parts of algae. However, not all fish have the right kinds of enzymes to break down algae. So, how are they able to get nutrients from algae that are hard to digest?

\section{MICROBES HELP DIGEST FOOD}

On land, we know a lot about how herbivores can digest complex polysaccharides in plants, which are structurally similar to algae. Most herbivores rely on tiny microbes that live inside their intestine to break down plants. These special gut microbes have evolved the enzymes they need to get energy from food, and herbivores, like cows, rely on their gut microbes to break down the grass and hay they eat into molecules they can absorb [1]. Microbes play a really important role in allowing these animals to get energy from foods they could not eat on their own. While we know a lot about this relationship and how it works with land animals, how it works in sea animals is largely 
Figure 1

Examples of different types of marine algae, or seaweeds, including brown, red, and green types. Each type of algae has different chains of sugars, known as polysaccharides, which help make up their cells. This means that each fish needs special kinds of enzymes, or molecular scissors, to help break each alga (singular of algae) down into smaller nutrients that are easier to digest. If they do not have the right enzymes, then they will not be able to break down their algae food.

\section{TRANSCRIPT}

Also known as messenger RNA, it is a copy of a piece of the cell's DNA. It is an instruction for the cell to know how to build different types of proteins, such as enzymes.

\section{EPULOPISCIUM}

A large microbe (bigger than a width of a hair and smaller than a frog egg) that has been discovered to live inside the stomachs of certain kinds of tropical surgeonfishes.

\section{Chains of sugars that help make up the cells of algae}

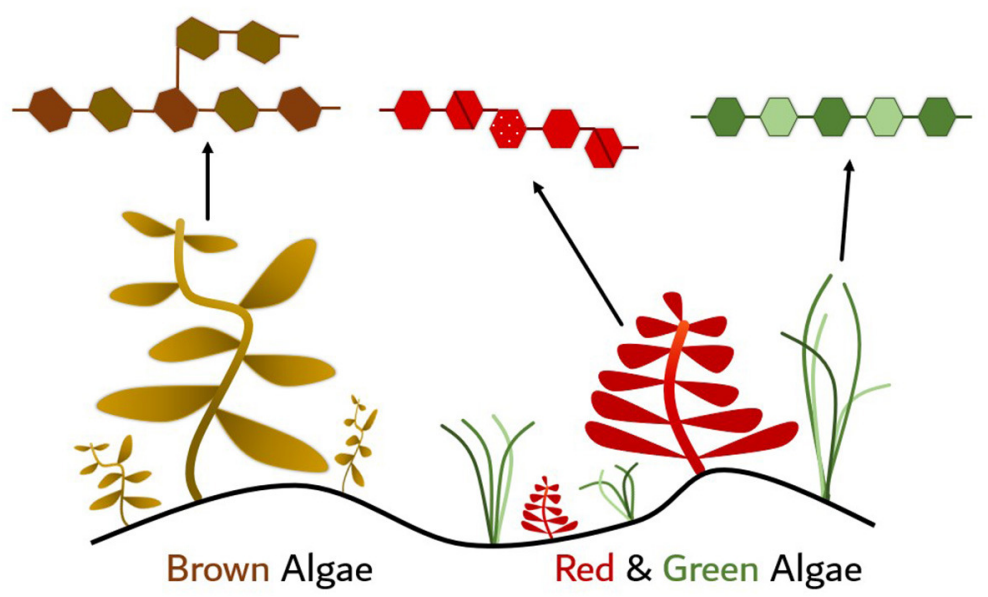

Figure 1

unknown. It is important to learn about how marine animals, like fish, digest their food because it allows us to better understand what they can eat and how they share different species of algae between themselves [2].

Therefore, the goal of this study was to take a first look into the gut microbe community of herbivorous coral reef fish to understand how important the gut microbes are in helping digestion, and to see if different fish have different gut microbe communities or not.

\section{WHAT WE DID}

To understand how herbivorous fishes rely on their gut microbes to digest algae, we collected samples from the stomachs of herbivorous surgeonfishes, like Bluespine unicornfish and Sohal surgeonfish, in the Red Sea. We collected fish that we knew ate different kinds of algae to see if differences in diet would change the gut microbes of the fish. Next, we had to see if the microbes had the right tools, or enzymes, that were required to break down the algae that were eaten. To do this, we looked at the transcripts, which are like building codes that cells use to make molecules like enzymes, made by the fish's gut microbes!

\section{WHAT WE FOUND}

First, we found that of all the microbes in the stomachs of all the fish we sampled, there was one kind of microbe that was most common-Epulopiscium. Epulopiscium (pronounced "E-pool-ohpiss-ee-um") is a giant microbe, more than 1,000 times larger than other common gut microbes, and as large as the width of a human 
Figure 2

A diagram showing differences in the gut microbes between two kinds of surgeonfishes that eat different types of algae. Bluespine unicornfish eat mostly brown algae and have giant microbes of Type J Epulopiscium, while Sohal surgeonfish eat mostly red and green algae and have Type A1 Epulopiscium, shown in the small graphs showing the relative amount of each giant microbe type. These giant microbes, about the size of the width of a human hair, are specialized to only be able to break down the kinds of algae their host fish like to eat. They do so by breaking apart complex chains of sugars, called polysaccharides, into smaller, more digestible pieces with enzymes represented by the colored scissors. Stomach and microbe images are from BioRender ${ }^{\odot}$ and fish images are from FishBase.

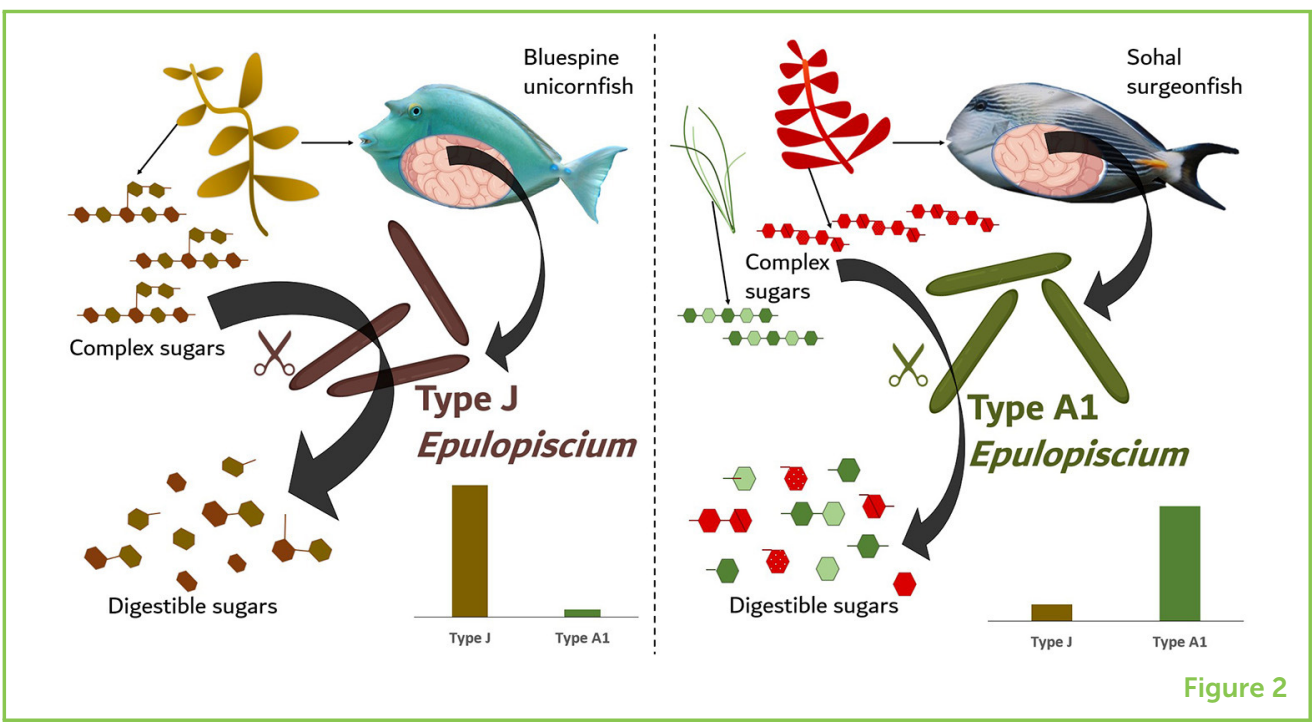

hair! Interestingly, not only did this large microbe dominate the gut microbe community, but different fish were found to have different types of Epulopiscium living inside them (Figure 2)! The fish that ate mostly brown algae had types of Epulopiscium living in their stomachs that were not found in the other fish's stomachs that ate mostly red and green algae. This showed that because these fish ate different algae, they needed a different kind of gut microbe community to digest their food.

Indeed, when we looked at the enzymes made by these giant microbes, we found that they produced certain enzymes that had the ability to break down the different components of the algae that fish fed on. This means herbivorous fishes that eat brown algae have stomach microbes with the enzyme machines needed to break down brown algae. These same brown algae-eating gut microbes would not be as successful at breaking down green or red algae. What we discovered for the first time, is that herbivorous fishes contain special groups of gut microbes with the enzymatic tools needed to break down the specific types of algae they eat! This was really amazing, especially since all this digestion seems to be led by the giant Epulopiscium. In other animals, especially land mammals, there is a more diverse community of gut microbes that all help break down plant matter [3]. It turns out that tropical herbivorous fishes have evolved a different, and perhaps unique, way of digesting the complex algae they eat!

We even found that the amount of this giant microbe and its enzymes changes inside the stomach of the fish throughout the day (Figure 3). After herbivorous fishes wake up, they start their day looking for algae to eat, and spend most of their day looking for their favorite algae foods. During the day when they are actively eating, the giant microbe Epulopiscium is the most active and produces a lot of enzymes to help break down the algae. But at night when the fish is not eating 
Figure 3

A graph showing the feeding activity of a Sohal surgeonfish over the course of a day. We found that the activity of the giant microbe Epulopiscium closely follows the feeding activity of its host fish, providing evidence that they play an important role in helping the fish digest the algae it is eating during the day. The activity of the giant microbe is higher than the feeding activity because it has to digest the algae in the stomach of the fish after it eats the algae. The microbe image is from BioRender ${ }^{\odot}$ and the fish image is from FishBase.

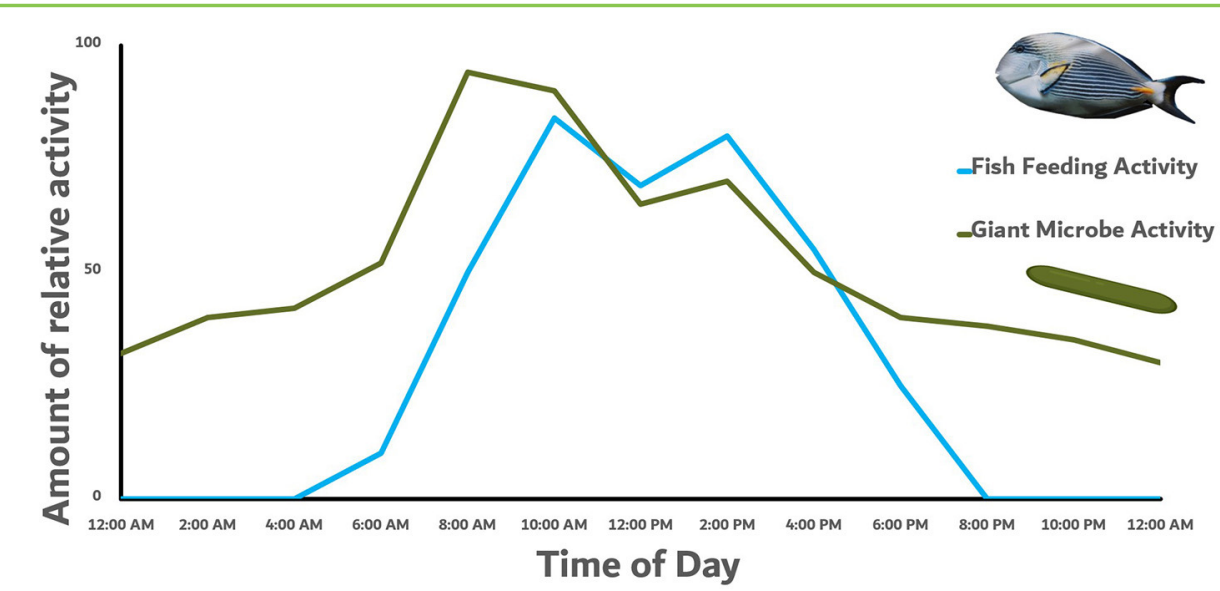

Figure 3

and rests, Epulopiscium slows down and stops producing so many of these enzymes since there is not any new algae in the stomach for it to help digest. Because the activity of Epulopiscium fluctuates along with the amount of algae the fish eats over a full day, this provides strong evidence that these fish rely heavily on their Epulopiscium gut microbes to help break down the algae they eat!

\section{WHY DOES THIS MATTER?}

It may seem obvious that fish gut microbe communities have adapted themselves to the diet of the fish they live inside. However, this is something no one has described in detail before. This discovery of a close relationship between the Epulopiscium microbe and the host fish diet has big implications for how we view plant-eating behavior on coral reefs. First, these consistent differences in types of gut microbes may provide a way for herbivorous fishes to occupy the same reef and lower competition for limited food items. If they can only consume and digest certain algae, then they are less likely to eat algae that other species are specialized to digest. Second, this means that these fish may be more limited in what they are able to eat than previously thought. Herbivorous fishes may not be able to get as much energy from different kinds of algae they normally do not eat. Things like pollution or climate change can change the type of algae species found on coral reefs and may change the herbivorous fish community to be made up of only those that can digest the most common algae. But we also know that gut microbe communities may not always be stable and could change over time [4]. With changing algae communities, herbivorous fishes might be able to change their gut microbes for different kinds that are better at digesting algae. However, the flexibility of gut microbe communities is something we still know very little about in marine fish and is an important area for future research! 
These Red Sea surgeonfish have taught us a lot about how herbivorous fishes depend on their giant gut microbes to be able to eat algae. However, we have only looked at a few species and there are many different kinds of herbivorous fishes out there. The more we learn about this unique relationship between fish and their gut microbes in the Red Sea, the better we will be able to understand how herbivorous fishes are able to function here, and all over the world!

\section{ORIGINAL SOURCE ARTICLE}

Ngugi, D. K., Miyake, S., Cahill, M., Vinu, M., Hackmann, T. J., Blom, J., et al. 2017. Genomic diversification of giant enteric symbionts reflects host dietary lifestyles. Proc. Natl. Acad. Sci. U.S.A. 114:E7592-601. doi: $10.1073 /$ pnas.1703070114

\section{REFERENCES}

1. White, B. A., Lamed, R., Bayer, E. A., and Flint, H. J. 2014. Biomass utilization by gut microbes. Ann. Rev. Microbiol. 68:279-96. doi: 10.1146/annurev-micro-092412-155618

2. Miyake, S., Ngugi, D. K., and Stingl, U. 2015. Diet strongly influences the gut microbiota of surgeonfishes. Mol. Ecol. 24:656-72. doi: 10.1111/mec.13050

3. Ley, R. E., Hamady, M., Lozupone, C., Turnbaugh, P. J., Ramey, R. R., and Bircher, J. S., et al. 2008. Evolution of mammals and their gut microbes. Science 20:1647-51. doi: 10.1126/science.1155725

4. Jones, J., DiBattista, J. D., Stat, M., Bunce, M., Boyce, M. C., Fairlough, D. V., et al. 2018. The microbiome of the gastrointestinal tract of a range-shifting marine herbivorous fish. Front. Microbiol. 9:2000. doi: 10.3389/fmicb.2018.02000

SUBMITTED: 01 July 2019; ACCEPTED: 27 March 2020;

PUBLISHED ONLINE: 29 May 2020.

EDITED BY: Rúben Martins Costa, King Abdullah University of Science and Technology, Saudi Arabia

CITATION: Tietbohl MD, Ngugi DK and Berumen ML (2020) A Unique Bellyful: Extraordinary Gut Microbes Help Herbivorous Fish Eat Seaweeds. Front. Young Minds 8:58. doi: 10.3389/frym.2020.00058

CONFLICT OF INTEREST: The authors declare that the research was conducted in the absence of any commercial or financial relationships that could be construed as a potential conflict of interest.

COPYRIGHT @ 2020 Tietbohl, Ngugi and Berumen. This is an open-access article distributed under the terms of the Creative Commons Attribution License (CC BY). The use, distribution or reproduction in other forums is permitted, provided the original author(s) and the copyright owner(s) are credited and that the original publication in this journal is cited, in accordance with accepted academic practice. 
No use, distribution or reproduction is permitted which does not comply with these terms.

\section{YOUNG REVIEWERS}

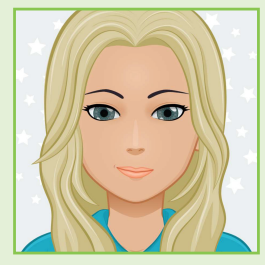

\section{ALANA, AGE: 12}

My name is Alana and I like to read all sorts of books and draw. My favorite color is blue and my favorite animal changes very often. My favorite book character is Percy Jackson.
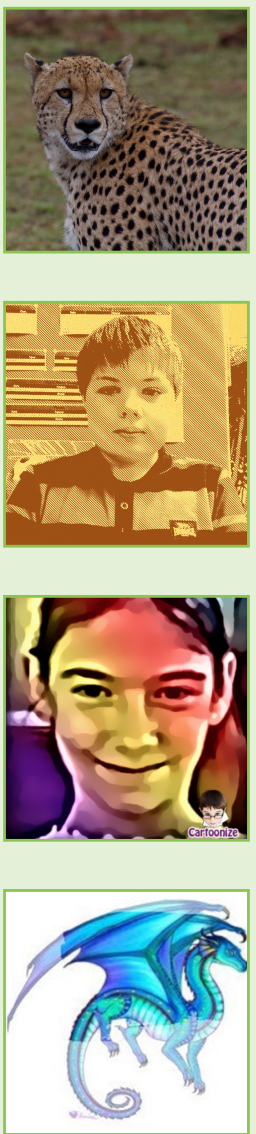

\section{IDHANT, AGE: 12}

Hi. I like traveling. I also like Lego. I have lived in France for around a year. I like photography. I am from India. I like reading, science, and wildlife. Okay. Bye.

\section{KONSTANTIN, AGE: 12}

I am from Kalinigrad, Russia. I have one sister who is 1 year old. I like programming and snorkeling. My favorite food is nigiri. I have been in five countries.

\section{LILIAN, AGE: 11}

$\mathrm{Hi}$, my name is Lili! I am 11 years old, and I am from Denver, Colorado, in the States. I like to read, especially Percy Jackson. I hope you like our article.

\section{SHIRHAN, AGE: 12}

Hi my name is Shirhan and I grew up in Boston. I love to read lots of books mostly Wing of Fire and I hope you like our article!

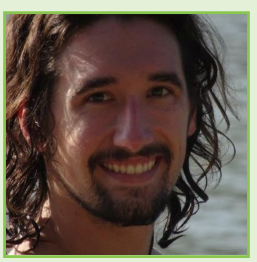

\section{AUTHORS}

\section{MATTHEW D. TIETBOHL}

Matt first found his love for the sea lifting up rocks in the intertidal zone of Jamaica, and he has barely looked back since. Matt has always been amazed by the diversity of species and shapes found below the surface of the sea. Combined with his love of spending time outdoors and never-ending curiosity, he found himself pursuing a Master's degree and then a Ph.D. in Saudi Arabia, studying the Red Sea. He is thrilled to be learning more about herbivorous reef fishes and exciting new techniques to better understand how they use and help coral reefs around the world. *matthew.tietbohl@kaust.edu.sa 


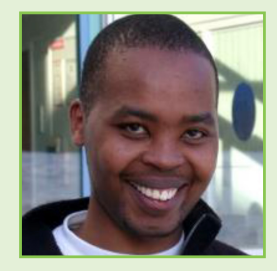

\section{DAVID KAMANDA NGUGI}

Dr. David Kamanda Ngugi is a microbe ecologist with a special focus on marine ecosystems. He is most interested in using cutting-edge techniques to understand the evolutionary adaptations and roles of "rare" microbes in the ocean. Dr. Ngugi has studied microbes all over the world, from Kenya to Saudi Arabia, Germany and many more places. His work is focused on teaching key information about the roles microbes play in nutrient cycling, extreme environments, and gut systems, like herbivorous fishes!

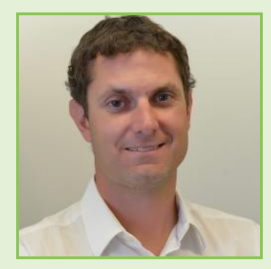

\section{MICHAEL L. BERUMEN}

Dr. Michael Berumen first developed his love for underwater life while mucking around the lakes and rivers of Arkansas, USA. He went on to study butterflyfishes on the Great Barrier Reef in Australia, and later focused his studies on movement and connectivity in coral reef fish. He now works in Saudi Arabia where his lab not only studies fish movement, but many other exciting aspects of ecology and biodiversity. As Mike tells all his students, there is always something exciting to learn on every trip out to sea! 